TURIZAM

Volume 22, Issue 3

121-132 (2018)

ORIGINAL

SCIENTIFIC PAPER

\title{
Environment Friendly Practices of Congress Hotels: Examples from Antalya Region of Turkey
}

\author{
Aksu Akinn ${ }^{A}$, Demir Ayşegül ${ }^{B}$, Öz Kadir ${ }^{B}$, Uğur Arihan Mehmet ${ }^{B}$ \\ Received: May 2018 | Accepted: September 2018
}

DOI: 10.5937/turizam22-18939

\begin{abstract}
Beside the economic effects of tourism, possible negative environmental effects should be taken in consideration. Generally, tourism activities affect natural areas, the flora and fauna of nature. To prevent negative effects of tourism development and protect nature both governments, and non-governmental organizations, are trying to force some measures on tourist establishments. It seems behaviors of human and interest of public will solve nature-related problems in the future. In hospitality related literature, it is possible to find out different researches showing environment friendly practices, products and effects of tourism. In this study, national congress participants' evaluations about their hotels' environment friendly practices were examined so as to draw attention importance of environment friendly practices for tourism. Suitable to the latest trends, national congress participants in the sampled hotels are sensitive to environmental friendly practices in general. It can be said that there is a positive and meaningful relationship between environmentally friendly practices and the intention to purchase.
\end{abstract}

Key words: environment friendly, congress hotels, Turkey, Antalya

\section{Introduction}

Global travel and tourism will contribute \$ 7.9 trillion to the global economy in 2017 (www.wttc. org/-/media/files/reports/policy-research/coping-with-success---executive-summary.pdf). According to United Nations World Tourism Organization (UNWTO), different countries in the world hosted 1.1 billion international tourists in the first 10 months of 2017. According to the 2017 figures, Southern and Mediterranean Europe, North Africa and the Middle East were the leading continents and in terms of growth the top 5 source countries were; China, the Republic of Korea, the United States, Canada and İtaly (media.unwto.org/press-release/2017-12-14/ southern-and-mediterranean-europe-north-africa-and-middle-east-drive-touris). According to 2018 predictions of UNWTO, the international tourist growth rate will be around 4-5\% (www.turizmgazetesi.com/news.aspx?id=85186).

\footnotetext{
A Akdeniz University Faculty of Tourism , Antalya, Turkey, Corresponding Author e-mail:aaksu@akdeniz.edu.tr

B Akdeniz University Social Sciences Institute, Antalya, Turkey
} 
Except in times of crises, continuous growth of international tourism movements in the world, every year attract the attention of governments to the tourism industry. Since international tourism movements mean foreign exchange, many governments especially in developing countries orient most of their power to the tourism industry (Neto, 2003). In fact, the tourism industry affects both tourist sending and receiving countries. In terms of tourist receiving countries, the main tourist establishments that serve the domestic sectors of transportation, hospitality and entertainment are economically affected in a positive way (Raza et al., 2017).

Beside the economic effects of tourism, possible negative environmental effects should be taken in consideration. Generally, tourism activities affect natural areas, the flora and fauna of nature (Tomescu, 2011). Within the development of tourism, unnecessary use of natural resources and energy may be seen (Leonidou et al., 2013). Even though tourism needs natural environment, it places an enormous pressure on nature (Bohdanowicz, 2006).

In order to prevent the negative effects of tourism development and protect nature both governments, and non-governmental organizations are trying to force some measures on tourism establishments. Generally, they take the interest of communities on being "green" (Chan,Wong, 2006). At the same time, travelers also observe and demand green activities at tourist establishments. In this atmosphere tourism managers in a way, must deal with the environment (Bohdanowicz, 2006) and its share in the budget. After facing climate change in the world, 191 countries and European Union members have signed Kyoto Protocol and started to decrease emissions of greenhouse gases (Pieri et al., 2016). Despite these attempts, UNWTO predicted a $130 \%$ rise in carbon dioxide emissions by 2035 because of air travels' and lodging establishments' operations (Manganari et al., 2016).

Generally speaking, it seems, human behavior and public interest will solve nature-related problems in the future (Jang et al., 2015) but, especially with the main pressure coming from customers, hoteliers will no longer regret the importance of environmental issues (Brown,1996). Chand and Garge have underlined results of research in the USA alone, 43 million tourists named themselves as eco-friendly tourists (Chand, Garge, 2017). Even on cruises, environmental activities can be found in order to decrease environmental impacts (Han et al., 2016).

\section{Environment Friendly Practices of Hotels}

Under huge pressure coming from different sides and growing awareness regarding the environment (Nimri et al.,2017:43), hoteliers have started environmental friendly practices. Among these; energy (low energy or energy conserving lighting), water conservation, recycling and waste reduction, hotel bath amenities (made without artificial ingredients), room keys (made from polyvinyl chloride), cleaning products (made with bio-based oils), food preparation (using fresh, local and seasonal products), menu selection (integrating organic produce), spas (integrating natural and organic products) (www.thebalance.com/sustainability-and-eco-friendly-hotel-initiatives1223545), furniture (integrating recycled wood), materials (using limited fossil fuels), hotel structure (allowing more ventilation), solar panels, electric cars and planting trees etc. (www.followgreenliving.com/characteristics-eco-friendly-hotel/).

Most of the environmental friendly practices need the managerial support of hoteliers where the rest can be realized with the valuable help of hotel workers and hotel customers (controlling lights, reuse of towels etc.) (Rahman et al., 2015). In fact, environment friendly practices enable decreasing operational costs of hotels and give important support to market- 
ing efforts of hotels. Since customers' selection decisions have changed towards environment friendly hotels, hoteliers pull them more easily to their hotels by benefiting from environmental caring practices (Leonidou et al., 2013). Despite customer pulling advantage, still some hoteliers are not sure of investing in environmental friendly practices due to their initial costs (Kang et al.,2012). If a differentiation strategy is followed (Molina-Azorin et al., 2015) and/or popularity levels of the hotels are trying to be increased, generally hoteliers accept environmental caring practices.

Referencing Clausing (2008), Millar and Baloglu (2011) have stated that according to the Deloitte survey result, $34 \%$ of 1,155 business travellers seek out environmentally friendly hotels and $38 \%$ have looked for green lodging facilities. By observing and following trends, hotels have different and concrete environmental friendly practices; for example, in order to decrease carbon dioxide emission, Hilton Hotels put a target of $20 \%$ for the end of 2014 (Kim et al., 2012). Benefiting from Bohdanowicz et al. (2011) study, Rahman et al. (2015) underlined that 70 Hilton properties in continental Europe successfully reduced energy use per square meter by $15 \%$ and decreased water use and $\mathrm{CO}_{2}$ emissions per customer per night by $8 \%$ in a three-year period of time. Regarding receiving awards, "The Colony Hotel in Kennebunkport, Maine," can be given as another successful example. This hotel named itself as "green" and won lots of awards because of its environmental practices. In terms of saving, "The Hotel Bel Air in Los Angales" can be cited, due to its comprehensive environmental program that yielded a $\$ 10,000$ savings in 10 months. In addition to these examples, Hyatt Regency Chicago (waste reduction and recycling system) and Scottsdale (hotel personnel environment training program) can be mentioned because of their different practices (Enz, Siguaw, 1999). Starting from 1998, Accor Hotels announced their 65 water, waste and biodiversity related actions (Kim et al., 2012). Lastly, Marriott International experienced a decrease both in energy (by $11 \%$ ) and in water (by $8.2 \%$ ) consumption in a two-year period (Rahman et al., 2015). Based on the Green Lodging Calculator, Dimara et al. (2017) stated that with the help of reuse programs (towel and others), it is possible to save 210,000 gallons of water and 143 gallons of detergent on a yearly basis for hotels with 150 rooms.

In hospitality related literature, it is possible to find different researches showing environment friendly practices, products and effects of tourism. Rodriguez and Cruz (2007), Horng et al. (2017:45) mentioned the excessive using of natural resources and energy which goes parallel with the development of international tourism movements in the world. As a tourist, water usage can be more than everyday water usage, this fact was underlined by Juvan and Dolnicar (2017) based on Gössling (2015). Citing Dodds (2005), Kim and et al. (2012) stated that over $\$ 1$ billion worth of energy is annually consumed by hotels. If conventional hotels are focused, it can be said that they do more damage to the environment because of their non-cyclable goods, water and energy excessive consumptions (Barber, 2014) during conventions or meetings. Against excessive usages, hotels may realize certain attempts and practices. Naturally all applications will differ from one hotel to another according to their customer profile, budget, vision and experience in tourism sector. In most cases, hotel managements understand the importance of environmental friendly practices, but they may have limited knowledge and awareness (Leonidou et al., 2013). Citing Wan (2007), Tang and Lam (2017) stated that hotel managers in Macao (China) do not buy into the positive effect of environmental management on competitiveness. In fact, customers have desire to support environmental practices and ready to pay more (Dimara et al., 2017). 


\section{Research Methodology}

In this study, national congress participants' evaluations about their hotels' environment friendly practices were investigated. In order to have concrete and correct answers, two 5 -star congress hotels (operating in Belek Region of Antalya) were selected as a sample. The authors selected the Antalya Region as main tourist region in Turkey. Since it was difficult to collect data from all 5 Star Hotels in the Antalya Region, a simple random sampling technique was used for defining the sample. The research was conducted between October and November period in 2016. Questionnaires were answered by the participants of two different national congresses (33rd National Gastroenterology Congress and 3rd Symposium of Medicinal and Aromatic Plants) which were organized in two sampled 5-star hotels. Totally 200 questionnaires were taken into consideration. SPSS 20.0 was used for evaluating the data.

Proposals between 1 and 17, were taken from Giritlioğlu and Güzel (2015), between 18 and 22, were taken from Sox et al. (2013) and between 23 and 25, were taken from Han et al. (2011). For demographical characteristics of the sample, frequency analysis, for environment friendly attitude and purchase intention reliability analysis, for environment friendly practices and purchasing intent relation correlation analysis, for the relationship between environment friendly practices and purchasing intention regression analysis, for the differences of attitudes towards environment friendly practices t-test and for the differences of participants' attitudes towards environment friendly practices one-way Anova test were done and for environment friendly applications scale, arithmetic mean and standard deviation values were calculated by the authors.

\section{Findings and Discussion}

When the distribution of the congress participants in the questionnaire is examined (See Table $1)$, it is seen that $45.0 \%(n=90)$ of the 200 participants are female and $55.0 \%(n=110)$ of the participants are male. When the distribution of the participants by their age is considered, it is seen that most of them are between the ages of $31-40(n=89 ; 44.5 \%)$. At the same time, $0.5 \%$ $(n=1)$ of the participants were between the ages of 20 and under; $17.5 \%(n=35)$ were between $21-30,27.0 \%(n=54)$ between the ages of $41-50$ and $10.5 \%(n=21)$ were 51 and over years of age.

When the data on the educational levels of the participants are examined, it was seen that $55.5 \%(n=111)$ of the majority of the participants were composed of the participants have postgraduate education, $36.5 \%(n=73)$ undergraduate; $5.5 \%(n=11)$ of associate degree; $2.5 \%(n=$ 5) were composed of high school graduate people.

When participants were asked whether they had previously stayed at an environmentally friendly congress hotel $60.0 \%(n=120)$ stated that accommodated, $40.0 \%(n=80)$ specified that not accommodated. When occupational groups of persons participating in the questionnaire are examined $16.0 \%(n=32)$ Engineer, $11.0 \%(n=22)$ Academician, $7.5 \%(n=15)$ Sales marketing, $54.0 \%(n=108)$ Health care worker and $11.5 \%(n=23)$ appears to be included in other occupational groups. 
Table 1. The Demographic Characteristics of Participants Attending the Research

\begin{tabular}{|c|c|c|}
\hline & Number (n) & Percentage (\%) \\
\hline $\begin{array}{l}\text { Gender } \\
\text { Female } \\
\text { Male } \\
\text { Total }\end{array}$ & $\begin{array}{r}90 \\
110 \\
200 \\
\end{array}$ & $\begin{array}{l}45,0 \\
55,0 \\
100\end{array}$ \\
\hline $\begin{array}{l}\text { Age } \\
20 \text { and under } \\
21-30 \\
31-40 \\
41-50 \\
51 \text { and above } \\
\text { Total }\end{array}$ & $\begin{array}{c}1 \\
35 \\
89 \\
54 \\
21 \\
200\end{array}$ & $\begin{array}{r}0,5 \\
17,5 \\
44,5 \\
27,0 \\
10,5 \\
100\end{array}$ \\
\hline $\begin{array}{l}\text { Education } \\
\text { High school } \\
\text { Associate degree } \\
\text { Undergraduate } \\
\text { Postgraduate } \\
\text { Total }\end{array}$ & $\begin{array}{c}5 \\
11 \\
73 \\
111 \\
200\end{array}$ & $\begin{array}{c}2,5 \\
5,5 \\
36,5 \\
55,5 \\
100\end{array}$ \\
\hline $\begin{array}{l}\text { Accommodation at the Congress Hotel } \\
\text { Yes } \\
\text { No } \\
\text { Total }\end{array}$ & $\begin{array}{c}120 \\
80 \\
200\end{array}$ & $\begin{array}{c}60,0 \\
40,0 \\
100\end{array}$ \\
\hline $\begin{array}{l}\text { Occupation } \\
\text { Engineer } \\
\text { Academician } \\
\text { Sales marketing } \\
\text { Health care worker } \\
\text { Other } \\
\text { Total }\end{array}$ & $\begin{array}{c}32 \\
22 \\
15 \\
108 \\
23 \\
200\end{array}$ & $\begin{array}{c}16,0 \\
11,0 \\
7,5 \\
54,0 \\
11,5 \\
100\end{array}$ \\
\hline $\begin{array}{l}\text { Congress / Symposium } \\
\text { 3rd Symposium on Medicinal and Aromatic Plants } \\
\text { 33rd National Congress of Gastroenterology } \\
\text { Total }\end{array}$ & $\begin{array}{c}50 \\
150 \\
200\end{array}$ & $\begin{array}{r}25,0 \\
75,0 \\
100\end{array}$ \\
\hline
\end{tabular}

A reliability analysis was conducted for the environment friendly attitude and purchase intention scales established within the research. According to this, it is determined that reliability coefficient of environment friendly attitude, Alpha $(\alpha)=0,94$; reliability coefficient of purchase intention, Alpha $(\alpha)=0,76$. According to these results, it can be said that the reliability level of the questionnaire used as a data collection tool in the survey is high. In Table 2, it is also possible to see the results of the reliability analysis.

Table 2. Reliability Coefficients of Scales

\begin{tabular}{|l|c|c|}
\hline Dimensions & Cronbach's Alpha & Statement number (N) \\
\hline Environment Friendly Attitude & 0,94 & 22 \\
\hline Purchase intention & 0,76 & 3 \\
\hline
\end{tabular}

When the average of statements about environment-friendly practices scale is considered (See Table 3), it is seen that the attitude of congress participants towards environment friendly practices is high values $(\overline{\mathrm{x}}=3,22 ; \mathrm{sd}=0,80)$.

When the answers given by the participants to the statements in the questionnaire are examined it is seen that the highest average is 'There are applications for smoking in congress 
hotels' $(\overline{\mathrm{x}}=3,84)$. However, statements have lowest mean are 'The congress hotels have food-saving applications' $(\overline{\mathrm{x}}=2,69)$ 'Renewable energy resources are used in congresses hotels' $(\overline{\mathrm{x}}=2,83)$. In the light of this information, it is seen that the participants of the congress are paying more attention to the applications of cigarette use in environment friendly practices at the congress hotel, they seem to pay attention least for food-saving and renewable energy resources usage.

Table 3. Arithmetic Mean and Standard Deviation Values of Environment Friendly Practices Scale

\begin{tabular}{|c|c|c|}
\hline & $\begin{array}{l}\text { Arithmetic } \\
\text { Mean }(\bar{X})\end{array}$ & $\begin{array}{c}\text { Standard } \\
\text { Deviation (Sd) }\end{array}$ \\
\hline GENERAL SCALE & 3,22 & 0,80 \\
\hline 1. Congress hotels have environmental policy and action plans related to it. & 3,41 & 1,16 \\
\hline 2. Congress hotels have department of environmental activities. & 3,32 & 1,18 \\
\hline 3. Congress hotels have an environmental management system. & 3,46 & 1,12 \\
\hline 4. Congress hotels have internationally accepted sustainability certificates. & 3,57 & 1,12 \\
\hline $\begin{array}{l}\text { 5. Energy consumption, electricity consumption and general energy consumption } \\
\text { in the congress hotels are followed. }\end{array}$ & 3,39 & 1,21 \\
\hline $\begin{array}{l}\text { 6. Maintenance and repair of all the installations and equipment is done } \\
\text { periodically in the congress hotels. }\end{array}$ & 3,52 & 1,16 \\
\hline 7. In congress hotels is provided training for sustainability to the staff. & 3,36 & 1,15 \\
\hline $\begin{array}{l}\text { 8. Congress hotels have value systems and receiving opinions for sustainability } \\
\text { from customers. }\end{array}$ & 3,11 & 1,26 \\
\hline $\begin{array}{l}\text { 9. Congress hotels pay attention to the fact that the devices and machines they } \\
\text { use are highly efficient and consume little energy. }\end{array}$ & 3,33 & 1,12 \\
\hline 10. There are applications for smoking in congress hotels. & 3,84 & 1,13 \\
\hline $\begin{array}{l}\text { 11. Congress participants are given information on how to make them behave in } \\
\text { an environmental friendly way. }\end{array}$ & 2,88 & 1,25 \\
\hline $\begin{array}{l}\text { 12. Congress hotels contribute to the preservation of the near historical, natural } \\
\text { and cultural values. }\end{array}$ & 2,95 & 1,28 \\
\hline 13. Architectural designs of congress hotels are sensitive to the environment. & 3,06 & 1,28 \\
\hline $\begin{array}{l}\text { 14. Building materials used in the construction of congress hotels are sensitive to } \\
\text { the environment. }\end{array}$ & 2,88 & 1,24 \\
\hline 15. Renewable energy resources are used in congresses hotels. & 2,83 & 1,37 \\
\hline $\begin{array}{l}\text { 16. Separation is done according to plastic, paper and glass type for waste in the } \\
\text { congress hotels. }\end{array}$ & 3,23 & 1,30 \\
\hline 17. Environmental labeled materials are used at congresses hotels. & 3,08 & 1,19 \\
\hline 18. Congress hotels offer different alternatives for plastic water bottles. & 2,88 & 1,40 \\
\hline 19. Congress hotels use environmentally friendly cleaning materials. & 2,99 & 1,25 \\
\hline $\begin{array}{l}\text { 20. The congress hotels provide service facilities for the transportation needs of } \\
\text { the participants. }\end{array}$ & 3,71 & 1,26 \\
\hline 21. The congress hotels have food-saving applications. & 2,69 & 1,29 \\
\hline 22. There is well-trained staff on sustainability at the congress hotels. & 3,18 & 1,20 \\
\hline
\end{tabular}

Scale: $1=$ strongly disagree, $2=$ do not agree, $3=$ neither agree nor disagree, $4=$ agree, $5=$ absolutely agree 
When the average of statements regarding the intention to purchase is considered (See Table 4), it is seen that the intention of purchasing people staying in congress facilities sensitive to environmental friendly practices is high $(\overline{\mathrm{x}}=3,53$; $\mathrm{sd}=1,04)$. When respondents' responses to the statements in the questionnaire are examined, it is seen that the highest average is ' $I$ will encourage my friends and relatives to stay at an environment-friendly congress hotels $(\overline{\mathrm{x}}=$ 3,80). On the other hand, the statements with the lowest mean are 'While I prefer congress, I stay at environment-friendly congress hotels' $(\overline{\mathrm{x}}=3,47)$ 'I am willing to pay more for environment-friendly congress hotels' $(\overline{\mathrm{x}}=3,30)$. In the light of this information, it is seen that against nonenvironment-friendly congress hotels, congress participants are less willing to stay in the environmentally friendly congress hotel and pay more.

Table 4. Arithmetic Mean and Standard Deviation Values of Purchase Intention Scale

\begin{tabular}{|l|c|c|}
\hline & $\begin{array}{c}\text { Arithmetic } \\
\text { Mean }(\bar{X})\end{array}$ & $\begin{array}{c}\text { Standard } \\
\text { Deviation (Sd) }\end{array}$ \\
\hline GENERAL SCALE & 3,53 & 1,04 \\
\hline 23. While I prefer congress, I stay at environment friendly congress hotels. & 3,47 & 1,25 \\
\hline $\begin{array}{l}\text { 24. I will encourage my friends and relatives to stay at an environment friendly } \\
\text { congress hotel. }\end{array}$ & 3,80 & 1,23 \\
\hline 25. I am willing to pay more for environment-friendly congress hotels. & 3,30 & 1,29 \\
\hline
\end{tabular}

In the analysis of the correlation (See Table 5), it was determined that there is a positive and meaningful relationship between the environmentally friendly practices and the intention to purchase in a generally acceptable way. There is a positive relationship between $(r=0,423$, $\mathrm{p}=, 000<0,05)$ eco-friendly practices and intent to purchase.

Table 5. Correlation Coefficients of Environment-Friendly Practices and Purchasing Intent Relation

\begin{tabular}{|l|c|c|}
\hline & (1) & (2) \\
\hline Environment-Friendly Practices (1) & 1 & \\
\hline Purchase Intention (2) &, $423^{* *}$ & 1 \\
\hline
\end{tabular}

** Correlation $(p<0.01)$ significant at level (2-tail). * $N=200$

The model explains $17.5 \%\left(A . R^{2}\right)$ of intention to purchase. In other words, environment-friendly practices account for $17.5 \%$ of the change in intent to purchase. According to Table 6, the effect of purchasing on environment-friendly practices seems to be linear and positive. It is possible to say that when the number of environment-friendly applications increases one unit, the intention to purchase will increase by 0.544 (Beta1).

Model: Purchasing Intention $=\mathrm{f}$ (Environment-Friendly Practices)

$\mathrm{Y}=\mathrm{Bo}+\mathrm{B} 1$.XEFP

$\mathrm{Y}=(\mathrm{o}, 423) \cdot \mathrm{XEFP}$ 
Table 6. Simple Regression Analysis Examining the Relationships Between Environment-Friendly Practices and Purchasing Intentions

\begin{tabular}{|l|c|c|c|}
\hline \multicolumn{1}{|c|}{ INDEPENDENT VARIABLE } & BETA & T & SiG. (P) \\
\hline Environment-Friendly Practices &, 544 & 6,569 &, $000^{* *}$ \\
\hline F & \multicolumn{3}{|c|}{43,151} \\
\hline R & \multicolumn{3}{|c|}{, 423} \\
\hline R2 & \multicolumn{3}{|c|}{, 179} \\
\hline Adjusted R2 & \multicolumn{3}{|c|}{1,870} \\
\hline Durbin-Watson & \multicolumn{3}{|c|}{} \\
\hline
\end{tabular}

*The value is significant at 0.05 level **The value is significant at 0.01 level

As seen in Table 7, T test was implemented to determine whether the arithmetic mean of attitudes towards environment-friendly congress hotels of participants showed a significant difference by previously accommodation at the environment-friendly hotel variable. As a result of the independent group $t$ test, it was found that attitudes towards environment-friendly practices of participants $(\mathrm{t}=2,4.92 ; \mathrm{p}<.05)$ was different in terms of lodging in an environmentally friendly hotel previously. According to the results of the analysis, it can be said that the people who stay at an environment-friendly convention hotel have more sensitive to environmentally friendly practices than people who don't stay.

Table 7. The t-Test and Results of the Differences of Attitudes towards Environment-Friendly Practices of Participants by Previously Accommodation at the Environment-Friendly Hotel Variable

\begin{tabular}{|c|c|c|c|c|c|c|c|c|c|c|}
\hline \multirow{2}{*}{$\begin{array}{l}\text { Demographic } \\
\text { Features }\end{array}$} & \multirow{2}{*}{$\begin{array}{l}\text { Dependent } \\
\text { Variable }\end{array}$} & \multirow{2}{*}{ Groups } & \multirow{2}{*}{$\begin{array}{l}\text { Art. } \\
\text { Mean }\end{array}$} & \multirow{2}{*}{$\begin{array}{l}\text { Std. } \\
\text { Dev. }\end{array}$} & \multicolumn{3}{|c|}{$\begin{array}{c}\text { Levene's Test for Equality } \\
\text { of Variances }\end{array}$} & \multirow[t]{2}{*}{$\mathrm{t}$} & \multirow{2}{*}{$d f$} & \multirow{2}{*}{ Sig. } \\
\hline & & & & & & $\mathrm{F}$ & Sig. & & & \\
\hline Accommodation & $\begin{array}{l}\text { Environment- } \\
\text { Friendly } \\
\text { Applications }\end{array}$ & $\begin{array}{l}\text { Yes } \\
\text { No }\end{array}$ & $\begin{array}{l}3,33 \\
3,05\end{array}$ & $\begin{array}{l}, 78 \\
, 82\end{array}$ & $\begin{array}{l}\text { Equal } \\
\text { Not } \\
\text { equal }\end{array}$ & ,146 & ,703 & $\begin{array}{l}2,492 \\
2,469\end{array}$ & $\begin{array}{c}198 \\
164,071\end{array}$ & 015 \\
\hline
\end{tabular}

${ }^{*} p<.05$ level is meaningful.

As can be seen in Table 8, as a result of one-way analysis of variance (ANOVA) conducted to determine whether the participants' attitudes towards environmentally friendly practices show a meaningful difference by the variable of the occupation, it is found that the attitudes towards environmentally friendly practices $\left(\mathrm{F}_{3-1508}=3,446 ; \mathrm{p}<05\right)$ differs in terms of the occupation they are doing. After this process, it is necessary to determine which selected occupation resulted from the significant difference determined after ANOVA.

In order to decide which multiple comparison technique should be used after the ANOVA analysis, firstly whether the hypothesis that the variances of the group distributions are homogeneous with the Levene's test was tested and (variances ( $p>05$ ) were homogeneous) information discovered. For this reason Tukey HSD multiple comparison test was preferred.

According to the test results, the differences between levels environment-friendly attitudes of participants in the engineering profession and in the health profession are meaningful $(\mathrm{p}<.05)$. Participants in the engineering profession $(\overline{\mathrm{x}}=2,79)$ was lower than academicians $(\bar{x}=3,07)$, sales marketing $(\bar{x}=3,19)$, health care worker $(\bar{x}=3,35)$ and other $(\bar{x}=3,35)$ in terms of environmentally friendly attitude level. 
Table 8. One-Way ANOVA Test and Results Showing the Difference of Participants' Attitudes towards Environment-Friendly Practices by the Variable of Occupation

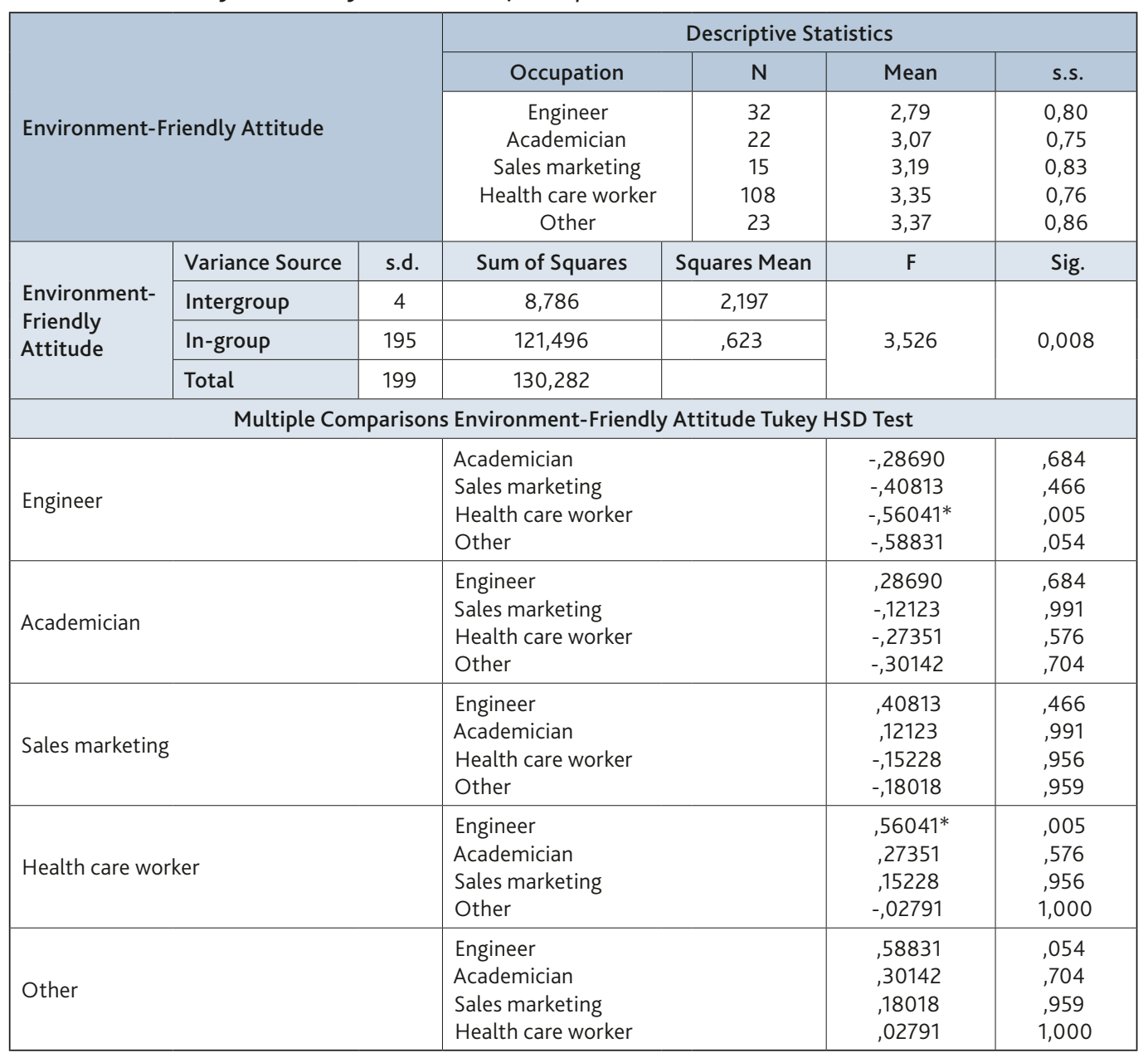

As seen in Table 9, T-test was conducted to determine whether the environmentally friendly attitudes of participants showed a significant difference from the arithmetic mean of symposium/congress variable. As a result of the independent group $t$ test, it was found that the level environmentally friendly attitude of participants $(\mathrm{t}=-4,124 ; \mathrm{p}<.05)$ was different in terms of the symposium or congress they attended. Based on the analysis results, it can be said that those who participated in the 33rd National Gastroenterology Congress are more sensitive towards environment friendly practices or more environmentally friendly attitudes than those attending the 3 rd Symposium of Medicinal and Aromatic Plants.

In addition to the findings, the differences in gender, age and educational level regarding environmentally friendly attitudes were examined but no significant difference was found. In addition, differences tests were conducted to determine whether the intention to buy differs according to demographic variables, but no significant differences were found. 
Table 9. The t-Test and Results of the Differences of Participants' Attitudes towards Environment-Friendly Practices by Congress They are Attending

\begin{tabular}{|c|c|c|c|c|c|c|c|c|c|c|}
\hline \multirow[t]{2}{*}{$\begin{array}{l}\text { Demographic } \\
\text { Feature }\end{array}$} & \multirow[t]{2}{*}{$\begin{array}{l}\text { Dependent } \\
\text { Variable }\end{array}$} & \multirow[t]{2}{*}{ Groups } & \multirow[t]{2}{*}{$\begin{array}{l}\text { Art. } \\
\text { Mean }\end{array}$} & \multirow[t]{2}{*}{$\begin{array}{l}\text { Std. } \\
\text { Dev. }\end{array}$} & \multicolumn{3}{|c|}{$\begin{array}{c}\text { Levene's Test for Equality of } \\
\text { Variances }\end{array}$} & \multirow[t]{2}{*}{$\mathrm{t}$} & \multirow[t]{2}{*}{$d f$} & \multirow[t]{2}{*}{ Sig. } \\
\hline & & & & & & $\mathrm{F}$ & Sig. & & & \\
\hline $\begin{array}{l}\text { Symposium / } \\
\text { Congress }\end{array}$ & $\begin{array}{c}\text { Environment- } \\
\text { Friendly } \\
\text { Practices }\end{array}$ & $\begin{array}{l}\text { Symposium } \\
\text { Congress }\end{array}$ & $\begin{array}{l}2,82 \\
3,35\end{array}$ & $\begin{array}{l}, 71 \\
, 79\end{array}$ & $\begin{array}{l}\text { Equal } \\
\text { Not } \\
\text { equal }\end{array}$ & ,942 & ,333 & $\begin{array}{l}-4,124 \\
-4,350\end{array}$ & $\begin{array}{c}198 \\
92,587\end{array}$ & ,000 \\
\hline
\end{tabular}

${ }^{*} p<.05$ level is meaningful.

\section{Conclusions and Suggestions}

Suitable to the latest trends, national congress participants in the sampled hotels are sensitive to environmental friendly practices in general. This result supports the importance of environmental friendly practices of hoteliers. It can be said that there is a positive and meaningful relationship between environmentally friendly practices and the intention to purchase. This result has a high value for tourism professionals. Managers and owners should take this knowledge into their considerations during marketing efforts. According to the results, it can be said that the people who stay at an environment-friendly convention hotel have more sensitive to environmentally friendly practices than people who don't stay. This result increases environment responsibility of hoteliers in terms of customers. In other words, if hoteliers are using "green, environment friendly or ecofriendly" terms in their slogans and marketing campaigns, they must convince their customers by sustaining tangible examples. Another research result is; attitudes of customers towards environmentally friendly practices are different according to their occupations. This fact may affect customer targeting processes of hoteliers. Lastly, no significant difference was found in terms of gender, age and educational levels of congress participants regarding environmentally friendly attitudes.

\section{Limitations}

Like all research, this research has some limitations. First, since the sample is too limited, it is not possible to generalize the results. Second, all results were based on replies from national congress participants in the sample, with no other verification.

\section{References}

Barber, N.A. 2014. Profiling The Potential "Green" Hotel Guest: Who Are They and What Do They Want? Journal of Hospitality \& Tourism Research 38(3), 361-387.

Bohdanowicz, P. 2006. Environmental Awareness and Initiatives in the Swedish and Polish Hotel Industries-Survey Results. Hospitality Management 25, 662-682.

Bohdanowicz, P., Zientara, P., Novotna, E. 2011. International Hotel Chains and Environmental Protection: An Analysis of Hilton's We Care! Programme (Europe, 2006-20o8). Journal of Sustainable Tourism 19(7), 797-816. 
Brown, M. 1996. Environmental Policy in the Hotel Sector: "Green” Strategy or Stratagem?. International Journal of Contemporary Hospitality Management 8(3), 18-23.

Chan, E.S.W., Wong, S.C.K. 2006. Motivations for ISO 14001 in the Hotel Industry. Tourism Management 27, 481-492.

Chan D,M., Garge, S. 2017. Eco Friendly Practices in Indian Hotel Industry: An Exploratory Study. International Journal of Hospitality \& Tourism Systems 10 (1), 63-70.

Clausing, J. 2008. Survey: Boomers More Likely to Go Green in Business Travel. Travel Weekly $67(2), 22$.

Dimara, E., Manganari, E., Skuras, D. 2017. Don't Change My Towels Please: Factors Influencing Participation in Towel Reuse Programs. Tourism Management 59, 425-437.

Dodds, R. 2005. Why Environmental Benchmarking Will Help Your Hotel. The Prince of Wales International Business Leaders Forum, London.

Enz, C.A., Siguaw, J.A. 1999. Best Hotel Environmental Practices. Cornell Hotel and Restaurant Administration Quarterly 10, 72-77.

Giritlioğlu, İ., Güzel, M.O. 2015. Otel İşletmelerinde Yeşil Yıldız Uygulamaları: Gaziantep ve Hatay Bölgesinde Bir Araştırma. Uluslararası Sosyal Araştırmalar Dergisi 8 (40), 889-904.

Gössling, S. 2015. New Performance Indicators for Water Management in Tourism. Tourism Management 46, 233-244.

Han, H. Jae, M., Hwang, J. 2016. Cruise Traveler's Environmentally Responsible Decision-Making: An Integrative Framework of Goal-Directed Behavior and Norm Activation Process. International Journal of Hospitality Management 53, 94-105.

Han, H., Lee, L.T., Lee, J., Sheu, C. 2011. Are Lodging Customers Ready To Go On Green? An Examination of Attitudes, Demographics and Eco-friendly Intentions. International Journal of Hospitality Management 30, 345-355.

Horng, J.S., Liu, C. H., Chou, S. F., Tsai, C. Y., Chung Y.C. 2017. From Innovation to Sustainability: Sustainability Innovations of Eco-Friendly Hotels in Taiwan. International Journal of Hospitality Management 63, 44-52.

Jang, S.Y., Chung, J.Y., Kim, Y.G. 2015. Effects of Environmentally Friendly Perceptions on Customer's Intentions to Visit Environmentally Friendly Restaurants: An Extended Theory of Planned Behavior. Asia Pasific Journal of Tourism Research 20 (6), 599-618.

Juvan, E., Dolnicar, S. 2017. Drivers of Pro-Environmental Tourist Behaviours are not Universal. Journal of Cleaner Production 166, 879-890.

Kang, K.H., Stein, L., Heo, C.Y., Lee, S. 2012. Consumers' Willingness to Pay For Green Initiatives of the Hotel Industry. International Journal of Hospitality Management 31,564-572.

Kim, Y.J, Palakurthi, R., Hancer, M. 2012. The Environmentally Friendly Programs in Hotels and Customers' Intention to Stay: An Online Survey Approach. International Journal of Hospitality \& Tourism Administration 13,195-214.

Leonidou, L.C., Fotiadis, T.A., Leonidou, C.N., Zeriti, A. 2013. Resources and Capabilities as Drivers of Hotel Environmental Marketing Strategy: Implications for Competitive Advantage and Performance. Tourism Management 35, 94-110.

Manganari, E.E., Dimara, E., Theotokis, A. 2016. Greening the Lodging Industry: Current Status, Trends and Perspectives for Green Value. Current Issues in Tourism, 19 (3), 223-242.

Millar, M., Baloglu, S. 2011. Hotel Guests' Preferences for Green Guest Room Attributes. Cornell Hospitality Quarterly 52 (3), 302-311.

Molina-Azorin, J.F., Tarí, J.J., Pereira-Moliner, J., López-Gamero, M. D., Pertusa-Ortega, E. M. 2015. The Effects of Quality and Environmental Management on Competitive Advantage: A Mixed Methods Study in the Hotel Industry. Tourism Management 50, 41-54. 
Neto, F. 2003. A New Approach to Sustainable Tourism development: Moving Beyond Environmental Protection. Natural Resources Forum 27, 212-222.

Nimri, R., Patiar, A., Kensbock, S. 2017. A Green Step Forward: Eliciting Consumers' Purchasing Decisions Regarding Green Hotel Accomodation in Australia. Journal of Hospitality and Tourism Management 33, 43-50.

Pieri, S.P., Stamos, A., Tzouvadakis, I. 2016. Reducing Tourist Carbon Footprint Through Strategic Mapping of the Existing Hotel Stock-Attica. International Journal of Sustainable Energy 35 (8), 734-745.

Rahman, I., Park, J., Chi, C.G. 2015. Consequences of "Greenwashing”: Consumers Reactions to Hotels' Green Initiatives. International Journal of Contemporary Hospitality Management 27 (6), 1054-1081.

Raza, S.A., Sharif, A., Wong, W. K., Karim, M. Z. A. 2017. Tourism Development and Environmental Degradation in the United States: Evidence From Wavelet-based Analysis. Current Issues in Tourism 20 (16), 1768-1790.

Rodriguez, F.J.G., Cruz, Y.D.M.A. 2007. Relation Between Social-Environmental Responsibility and Performance in Hotel Firms. Hospitality Management 26 (4),824-839.

Sox, C.B., Benjamin, S., Carpenter, J., Strick, S. 2013. An Exploratory Study of Meeting Planners and Conference Attendees' Perceptions of Sustainable Issues in Convention Centers. Journal of Convention \& Event Tourism 14, 144-161.

Tang, C.M.F., Lam, D. 2017. The role of extraversion and agreeableness traits on gen y's attitudes and willingness to pay for green hotels. International Journal of Contemporary Hospitality Management 29 (1), 607-623.

Tomescu, A.M. 2011. Aspects of Service Quality and Ecolabelling of Romanian Lodging Services. RePEc, 693-699.

Wan, Y.K.P. 2007. The Use of Environmental Management as a Facilities Management Tool in the Macau Hotel Sector. Facilities 25 (7/8), 286-295.

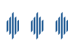

www.wttc.org/-/media/files/reports/policy-research/coping-with-success---executive-summary.pdf:(11.01.2018)

media.unwto.org/press-release/2017-12-14/southern-and-mediterranean-europe-north-africa-and-middle-east-drive-touris:(11.01.2018)

www.turizmgazetesi.com/news.aspx?id=85186:(19.01.2018)

www.thebalance.com/sustainability-and-eco-friendly-hotel-initiatives-1223545:(22.02.2018)

www.followgreenliving.com/characteristics-eco-friendly-hotel/(o7.03.2017) 